\title{
EVALUASI SIFAT FISIKA TANAH TYPIC HAPLUDULTS PADA EMPAT GENERASI TANAM KELAPA SAWIT PT SOCFIN INDONESIA DI KEBUN AEK LOBA KABUPATEN ASAHAN
}

\author{
Evaluation of Soil Physical Characteristic Typic Hapludults on Four Generations of Oil \\ Palm PT Socfin Indonesia in Aek Loba Estate Asahan District
}

Edison Parulian Sihombing*, Abdul Rauf, Rahmawaty, Erwin Nyak Akoeb Program Studi Magister Agroekoteknologi, Fakultas Pertanian, USU, Medan 20155

*Corresponding author : edisonsihombing645@yahoo.co.id

\begin{abstract}
Charges against oil palm plantations as the cause of soil degradation and as a ringleader of environmental damage, drought land and take nutrients in large quantities makes this study important. The purpose of this study to determine the effect of oil palm cultivation on the four generation of sustainable planting to changes in soil phisical characteristics Typic hapludults. Description of soil profiles and sampling was conducted at four sites representing generations of planting oil palm. As the control mixed crop that has not been planted with oil palm. Soil samples tested in the laboratory for each of the characteristics of soil physics. Results showed oil palm cultivation in soil Typic hapludults for four generations of plants continuously unchanged physical characteristics significant level. This shows that the cultivation of oil palm trees in a sustainable manner with the best management practise systems PT Socfindo can maintain the physical characteristics of the soil.
\end{abstract}

Keywords: $\quad$ Typic hapludults, soil degradation, planting generation

\begin{abstract}
ABSTRAK
Tuduhan terhadap perkebunan kelapa sawit sebagai penyebab degradasi tanah, kerusakan lingkungan, kekeringan dan sebagai tanaman mengambil hara tanah dalam jumlah yang besar menjadikan penelitian ini penting. Tujuan dari penelitian ini untuk mengetahui pengaruh budidaya tanaman kelapa sawit pada empat generasi tanam yang berkelanjutan terhadap perubahan karakteristik fisik tanah Typic hapludults. Deskripsi profil tanah dan pengambilan sampel dilakukan di empat lokasi yang mewakili generasi tanam kelapa sawit. Sebagai kontrol adalah kebun campuran yang belum pernah ditanam kelapa sawit. Sampel tanah diuji di laboratorium untuk masing-masing karakteristik fisik tanah. Hasil menunjukkan budidaya kelapa sawit di tanah Typic hapludults selama empat generasi tanam secara terus menerus tidak mengalami perubahan karakteristik fisika tanah yang signifikan. Ini menunjukkan bahwa budidaya tanaman kelapa sawit secara berkelanjutan dengan sistem manajemen praktis terbaik PT Socfindo dapat mempertahankan karakteristik fisik tanah.
\end{abstract}

Kata kunci : $\quad$ Typic hapludults, degradasi tanah, generasi tanaman 


\section{PENDAHULUAN}

Luas Kebun Aek Loba tahun $2016=$ $8.611,35 \mathrm{Ha}$ yang sudah mengalami beberapa kali peremajaan tanaman (replanting) dengan luas areal Generasi tanam pertama $(\mathrm{G} 1)=52,43$ Ha $(0,6 \%)$; Generasi Tanam II $(\mathrm{G} 2)=4.540,48$ Ha (52,7\%); Generasi Tanam III (G3) = 2.581,30 Ha dan Generasi Tanam IV $(\mathrm{G} 4)=$ 1.437,04 (Socfindo, 2016)

Utami dkk (2013) mengungkapkan bahwa alih fungsi hutan menjadi tanaman karet dan kelapa sawit mengakibatkan terjadinya degradasi sifat fisik dan kimia tanah. Bobot isi tanah pada lahan karet dan kelapa sawit lebih tinggi dibandingkan dengan lahan hutan, terutama pada lapisan atas. Menurut Kallarackal et al. (2004) perkebunan kelapa sawit sangat mengganggu persediaan air tanah untuk tanaman lain di luar kebun kelapa sawit. Pengurasan air tanah per batang pohon kelapa sawit dilaporkan memerlukan 20 sampai 40 liter air dalam sehari dan dapat menyerap air sampai kedalaman 5,2 meter.

Perkebunan Aek Loba yang $47 \%$ arealnya sudah mengalami lebih dari 2 kali peremajaan (3 - 4 generasi tanam), diduga telah menyebabkan perubahan karakteristik tanah yang berdampak pada degradasi tanah atau penurunan kualitas tanah. Menurunnya kualitas tanah akan berpengaruh pada kesuburan tanah dan pada efektifitas pemupukan sehingga berdampak pada penurunan produktivitas tanaman jika tidak ada upaya-upaya lain yang dilakukan. Di sisi lain, perkebunan kelapa sawit PT Socfindo di kebun Aek Loba yang sudah ditanam kelapa sawit lebih dari 92 tahun (hingga saat ini sudah 4 generasi tanam), tetap menghasilkan produktivitas yang tinggi pada setiap generasi tanam (rata-rata > 25 ton TBS/ ha/ tahun).

Penelitian ini memiliki hipotesa bahwa budidaya kelapa sawit pada beberapa generasi tanam di Perkebunan Aek Loba, PT.Socfindo pada jenis tanah Typic hapludults secara terus menerus menyebabkan perubahan karakteristik tanah secara tidak signifikan. Penelitian ini bertujuan untuk mengevaluasi pengaruh beberapa generasi tanam Kelapa Sawit (Generasi 1 s.d 4) terhadap perubahan karakteristik tanah pada jenis tanah Typic hapludults di Perkebunan Aek Loba, Kabupaten Asahan.

\section{BAHAN DAN METODE}

Penelitian ini dilaksanakan bulan Maret Juni 2016 di Perkebunan Aek Loba PT Socfin Indonesia yang berada di Kabupaten Asahan, terletak di antara 99 $32^{\prime} 56.41^{\prime \prime}$ - 99 $49^{\circ} 15.75^{\prime \prime}$ BT dan 2॰35'27.89" - 2³9'58.52" LU.

Penelitian ini mengamati perbedaan pada faktor generasi tanam sebagai faktor perlakuan, yakni 4 generasi tanam kelapa sawit ditambah 1 kebun campuran (non kelapa sawit) yang akan dibandingkan dengan aspek variabel karakteristik tanah sifat fisik. Dalam penelitian ini, faktor perlakuan tidak dikondisikan oleh peneliti, lokasi pengamatan baik di Generasi 0 (non sawit), Generasi 1, Generasi 2, Generasi 3 dan Generasi 4 merupakan perlakuan yang tersedia di lapangan. Dalam hal ini peneliti hanya mengamati karakteristik fisik tanah pada masing-masing faktor perlakuan dan menganalisis perbedaan yang terjadi antar generasi.

Bahan-bahan yang digunakan dalam penelitian ini adalah:

a. Peta seri tanah dari laporan survey tanah oleh Paramanathan ( 2004);

b. Data-data spasial pendukung lainnya (batas kebun, batas blok, jalan dan sungai)

c. Data sejarah tanaman kelapa sawit kebun Aek Loba, berupa peta-peta kebun sejak Generasi 1 tahun tanam 1924.

d. Data primer berupa hasil observasi lapangan dan hasil analisis laboratorium dari pengambilan sampel tanah dimana cara pengambilan sampel menggunakan cangkul atau dodos untuk sampel profil dan bor tanah.

Alat yang digunakan untuk penelitian ini yaitu : Global Positioning System (GPS), Soil Hand Bor, Munsell Soil Color Chart, cangkul untuk menggali profil, pisau untuk analisa horizon tanah, klinometer, kertas, pulpen, spidol permanen, dan lain-lain. 


\section{Pengamatan Profil Tanah}

Profil tanah diamati dengan membuat lubang 1,5 m x $1 \mathrm{~m}$ sampai kedalaman $150 \mathrm{~cm}$. Pembuatan profil tanah dilakukan pada 3 plot pada masing-masing generasi tanam kelapa sawit dan Generasi 0 yang tidak pernah ditanami kelapa sawit sebagai kontrol. Pemilihan lokasi profil tanah menggunakan metode systematic sampling (Sys) dalam Suganda et al (2006).

\section{Variabel Amatan/ Respon}

Variabel amatan dalam penelitian ini adalah karakteristik tanah yang terdiri atas sifat fisika tanah.

Tabel 1. Variabel amatan pada data profil tanah

\begin{tabular}{|c|}
\hline Variabel Amatan Anova pada Data Profil \\
\hline Bulk Density $\left(\mathrm{Y}_{1}\right)$ \\
\hline Porositas $\left(\mathrm{Y}_{2}\right)$ \\
\hline Air Tersedia $\left(\mathrm{Y}_{3}\right)$ \\
\hline
\end{tabular}

Pengamatan dilakukan dengan cara, pengambilan contoh di setiap lapisan tanah dalam lubang profil. Kemudian contoh tanah akan dianalisa di laboratorium untuk masingmasing karakteristik tanah.

1. Masing-masing variabel diuji normalitas dan kehomogenan ragamnya. Uji normalitas menggunakan statistic uji shapiro wilk (software SAS 9.4) dan kehomogenan ragam diuji dengan uji levene (software Minitab 17). Jika kedua asumsi terpenuhi, maka dapat dilanjutkan dengan analisis ANOVA.

2. Melakukan analisis ANOVA untuk setiap variabel amatan sesuai model penelitian yang dirancang dengan software Minitab 17.

3. Apabila dari hasil ANOVA diketahui statistik uji menghasilkan nilai $\mathrm{P}$ value atau Sig. di bawah $\alpha 5 \%$, maka dilakukan uji lanjut Tukey untuk membandingkan nilai antar generasi tanam kelapa sawit dengan menggunakan software Minitab 17.

\section{HASIL DAN PEMBAHASAN}

\section{Deskripsi Profil Tanah}

Dari hasil deskripsi profil berdasarkan Keys to Soil Taksonomy (Soil Survey Staffs, 2014) dan hasil analisa fisika serta kimia tanah tergolong ke dalam Typic Hapludult sesuai dengan hasil survei tanah semi-detil Aek loba, Aek Nabuntu, Aek Korsik, Aek Loba Timur dan Aek Kuasan Perkebunan Kelapa sawit di Kabupaten Asahan oleh Paramananthan (2004).

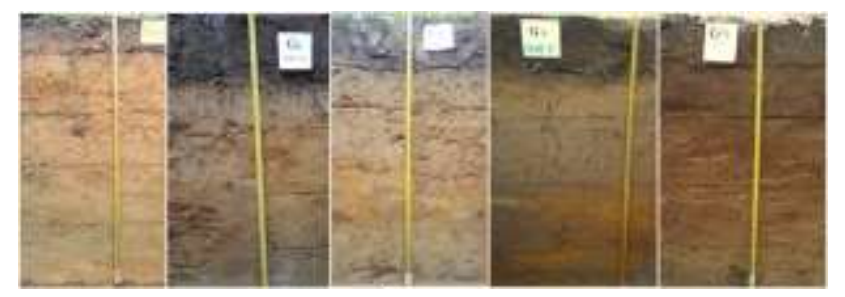

Gambar 1. Penampang Profil tanah Typic hapludults

Tabel 2. Hasil analisa tekstur tanah per generasi

\begin{tabular}{|c|c|c|c|c|c|}
\hline Generasi & $\begin{array}{c}\text { Lapi } \\
\text { san }\end{array}$ & Tekstur & $\begin{array}{c}\text { Pasir } \\
(\%)\end{array}$ & $\begin{array}{c}\text { Debu } \\
(\%)\end{array}$ & $\begin{array}{c}\text { Liat } \\
(\%)\end{array}$ \\
\hline \multirow[t]{5}{*}{$\begin{array}{c}\text { Generasi } \\
0\end{array}$} & I & Lempung Berpasir & 63.91 & 21.42 & 14.67 \\
\hline & II & Lempung Liat Berpasir & 64.41 & 4.00 & 31.59 \\
\hline & III & Lempung Liat Berpasir & 64.55 & 14.27 & 21.18 \\
\hline & IV & Pasir Berlempung & 74.62 & 17.69 & 7.69 \\
\hline & $\mathrm{V}$ & Lempung Berpasir & 67.78 & 24.56 & 7.66 \\
\hline \multirow[t]{5}{*}{$\begin{array}{c}\text { Generasi } \\
1\end{array}$} & I & Pasir Berlempung & 75.15 & 14.95 & 9.90 \\
\hline & II & Lempung Liat Berpasir & 64.58 & 14.67 & 20.75 \\
\hline & III & Lempung Liat Berpasir & 62.36 & 11.05 & 26.59 \\
\hline & IV & Pasir Berlempung & 82.02 & 10.60 & 7.38 \\
\hline & V & Pasir Berlempung & 85.89 & 7.15 & 6.96 \\
\hline \multirow[t]{5}{*}{$\begin{array}{c}\text { Generasi } \\
2\end{array}$} & I & Pasir Berlempung & 74.74 & 14.14 & 11.12 \\
\hline & II & Lempung & 46.95 & 28.36 & 24.69 \\
\hline & III & Lempung Liat Berpasir & 71.97 & 3.70 & 24.33 \\
\hline & IV & Lempung Berpasir & 78.70 & 3.82 & 17.48 \\
\hline & $\mathrm{V}$ & Pasir Berlempung & 89.19 & 3.68 & 7.13 \\
\hline \multirow[t]{5}{*}{$\begin{array}{c}\text { Generasi } \\
3\end{array}$} & I & Pasir Berlempung & 73.52 & 14.22 & 12.26 \\
\hline & II & Lempung Berpasir & 77.63 & 3.60 & 18.77 \\
\hline & III & Lempung Liat Berpasir & 72.12 & 7.01 & 20.87 \\
\hline & IV & Lempung Liat Berpasir & 70.57 & 6.99 & 22.44 \\
\hline & $\mathrm{V}$ & Pasir Berlempung & 82.27 & 3.58 & 14.15 \\
\hline \multirow[t]{5}{*}{$\begin{array}{c}\text { Generasi } \\
4\end{array}$} & I & Pasir Berlempung & 85.45 & 7.18 & 7.37 \\
\hline & II & Lempung Berpasir & 67.08 & 14.12 & 18.80 \\
\hline & III & Pasir Berlempung & 82.01 & 3.65 & 14.34 \\
\hline & IV & Lempung Berpasir & 71.97 & 10.47 & 17.56 \\
\hline & $\mathrm{V}$ & Lempung Berpasir & 75.35 & 7.01 & 17.64 \\
\hline
\end{tabular}


Variabel Karakteristik Fisik Tanah

\section{Analisis Keragaman Variabel Y1 (Bobot Isi Tanah / Bulk Density - BD)}

Nilai BD bervariasi bergantung pada kerekatan partikel-partikel tanah itu. Dari hasil ring sampel tanah di laboratorium, diketahui nilai BD pada G0 sedikit lebih tinggi dibandingkan dengan BD pada G1, G2, G3, dan G4 (Gambar 2). Walaupun sedikit lebih tinggi, namun jika dilihat per lapisan dalam one way Anova (Tabel 3), nilai BD diantara kelima generasi tersebut tidak berbeda nyata.

Tabel 3. Uji beda rata-rata bulk density $\left(\mathrm{gr} . \mathrm{cm}^{-3}\right)$ setiap generasi tanam dan lapisan tanah

\begin{tabular}{|c|c|c|c|c|c|c|}
\hline Generasi & G0 & G1 & G2 & G3 & G4 & Sig. \\
\hline Lapisan I & 1.22 & 1.24 & 1.23 & 1.20 & 1.20 & $0.9989 \mathrm{~ns}$ \\
\hline Lapisan II & 1.27 & 1.22 & 1.24 & 1.20 & 1.16 & $0.9705 \mathrm{~ns}$ \\
\hline Lapisan III & 1.31 & 1.11 & 1.25 & 1.26 & 1.19 & $0.8786 \mathrm{~ns}$ \\
\hline Lapisan IV & 1.36 & 1.30 & 1.30 & 1.27 & 1.20 & $0.9753 \mathrm{~ns}$ \\
\hline Lapisan V & 1.42 & 1.42 & 1.26 & 1.38 & 1.21 & $0.8499 \mathrm{~ns}$ \\
\hline
\end{tabular}

$5 \%=$ signifikan, $\mathrm{ns}=$ not significant.

\section{Analisis Keragaman Variabel Y2 (Porositas atau Total Ruang Pori)}

Porositas adalah isi seluruh pori-pori dalam suatu isi tanah utuh yang dinyatakan dalam persen, yang terdiri atas ruang diantaranya partikel pasir, debu, liat serta ruang diantara agregat-agregat tanah.

Nilai porositas bervariasi bergantung pada kerekatan partikel-partikel tanah itu dan berbanding terbalik dengan bulk density (BD). Dari hasil ring sampel tanah di laboratorium, diketahui nilai porositas pada G0 sedikit lebih rendah dibandingkan dengan porositas pada G1, G2, G3, dan G4 (Gambar 3). Walaupun sedikit lebih tinggi, namun jika dilihat per lapisan dalam one way Anova (Tabel 4), nilai porositas diantara kelima generasi tersebut tidak berbeda nyata. Hal ini dilihat dari nilai significant (Sig.) yang lebih besar dari $\alpha 5 \%$, baik pada Lapisan I, II, III, IV maupun V.
Tabel 4. Uji beda porositas (\%) per generasi tanam dan lapisan tanah

\begin{tabular}{|c|c|c|c|c|c|c|}
\hline Lapisamerasi & G0 & G1 & G2 & G3 & G4 & Sig. \\
\hline Lapisan I & 54.09 & 53.19 & 53.41 & 54.53 & 54.58 & $0.9989 \mathrm{~ns}$ \\
\hline Lapisan II & 52.21 & 54.09 & 53.19 & 54.70 & 56.25 & $0.9705 \mathrm{~ns}$ \\
\hline Lapisan III & 50.43 & 58.05 & 52.90 & 52.34 & 55.15 & $0.8786 \mathrm{~ns}$ \\
\hline Lapisan IV & 48.69 & 51.03 & 50.89 & 52.11 & 54.73 & $0.9753 \mathrm{~ns}$ \\
\hline Lapisan V & 46.32 & 46.50 & & & & \\
\hline
\end{tabular}

Note : Sig.=Signifikansi Oneway ANOVA pada $\alpha$ 5\%. Jika Sig. $<\alpha 5 \%$ $=$ signifikan, $\mathrm{ns}=$ not significant.

\section{Analisis Keragaman Variabel Y3 (Air tersedia)}

Perhitungan Air tersedia didapat dari selisih Kadar Air Kapasitas Lapang (KAKL) dengan Kadar Air Titik Layu Permanen (KATLP). Perhitungan ini dilakukan dari hasil analisis laboratorium pada ring sample. Banyaknya air tersedia bervariasi bergantung pada kadar air pada kapasitas lapang (pada $\mathrm{pF}$ 2.54) dan kadar air titik layu permanen (pada $\mathrm{pF}$ 4.2). Hasil analisa laboratorium, nilai Air Tersedia pada G0, G1, G2, G3, dan G4 (Gambar 4) berkisar diantara nilai rata-rata umum 9.0. Jika dilihat per lapisan dalam one way Anova (Tabel 5), air tersedia diantara kelima generasi tersebut tidak berbeda nyata. Hal ini dilihat dari nilai significant (Sig) yang lebih besar dari $\alpha$ $5 \%$, baik pada Lapisan I, II, III, IV maupun V.

Tabel 5. Uji beda air tersedia (\%) per generasi tanam dan lapisan tanah

\begin{tabular}{|c|c|c|c|c|c|c|}
\hline Gapisan & G0 & G1 & G2 & G3 & G4 & Sig. \\
\hline Lapisan I & 9.15 & 11.14 & 10.01 & 11.25 & 9.41 & $0.58 \mathrm{~ns}$ \\
\hline Lapisan II & 8.89 & 10.82 & 7.46 & 10.76 & 11.69 & $0.71 \mathrm{~ns}$ \\
\hline Lapisan III & 5.93 & 9.86 & 7.04 & 6.64 & 6.18 & $0.65 \mathrm{~ns}$ \\
\hline Lapisan IV & 6.84 & 10.18 & 10.66 & 9.11 & 5.24 & $0.34 \mathrm{~ns}$ \\
\hline Lapisan V & 8.22 & 11.39 & 8.22 & 10.57 & 9.51 & $0.62 \mathrm{~ns}$ \\
\hline
\end{tabular}




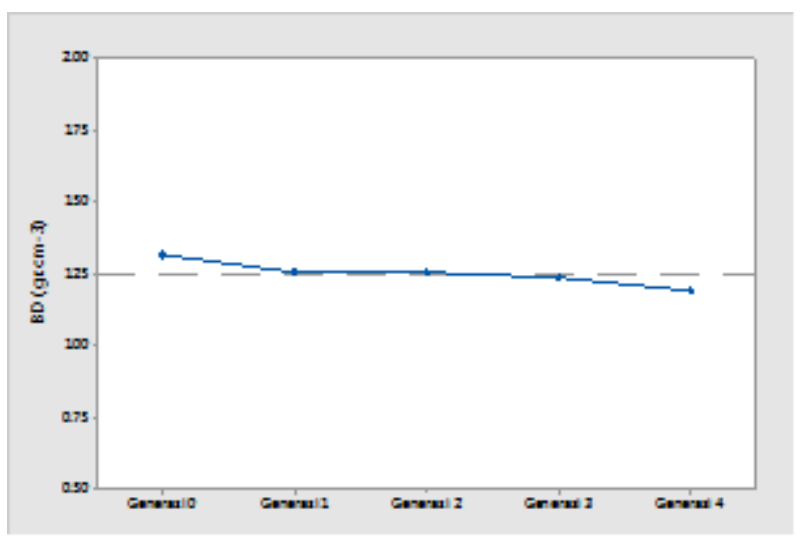

Gambar 2. Plot rerata pengaruh generasi tanam dan lapisan terhadap BD $\left(\right.$ gr. $\left.\mathrm{cm}^{-3}\right)$

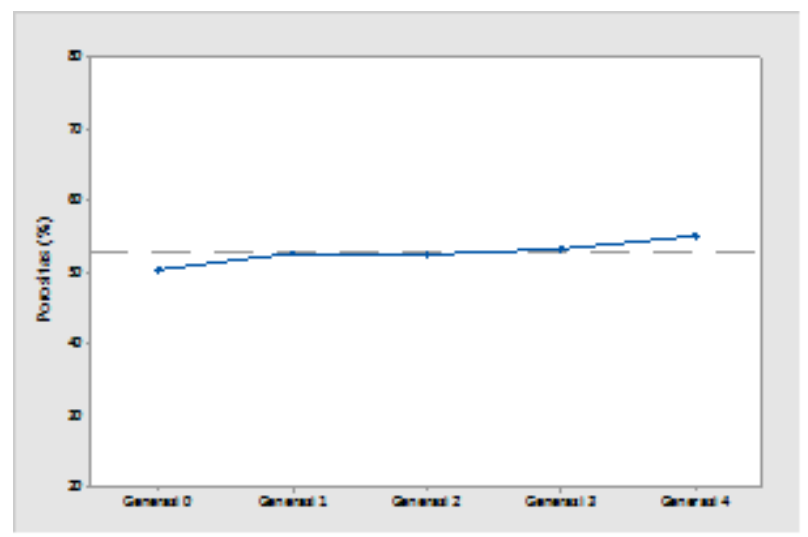

Gambar 3. Plot rerata pengaruh generasi tanam dan lapisan terhadap porositas (\%)

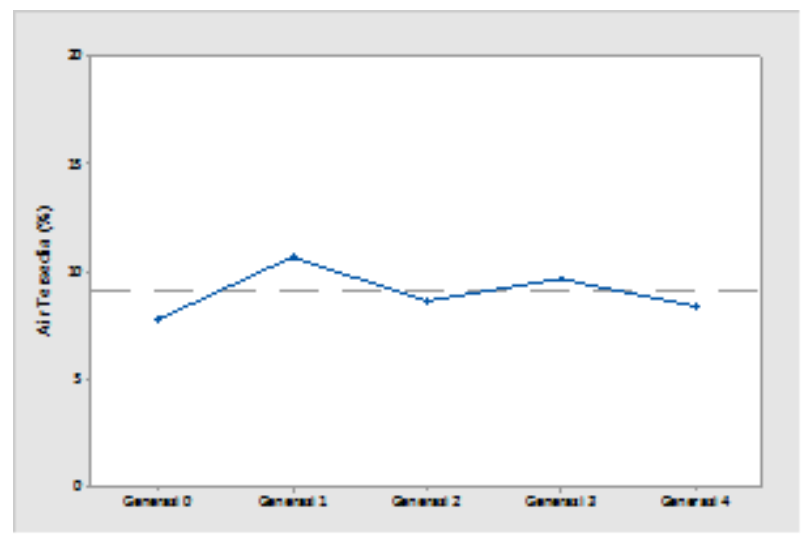

Gambar 4. Plot rerata pengaruh generasi tanam dan lapisan terhadap air tersedia (\%)

Dari data tekstur dan distribusi fraksi liat, terlihat bahwa pada Generasi 0 terjadi pencucian liat di Lapisan I dan II penumpukan liat pada Lapisan III, demikian halnya dengan Generasi 1 dan Generasi 2 terjadi pencucian liat di Lapisan I dan II penumpukan liat pada Lapisan III. Berbeda dengan Generasi 3 dan Generasi 4 distribusi fraksi liat didalam lapisan tersebar merata dan tidak terjadi pencucian dan penimbunan liat yang signifikan. Hal ini merupakan akibat dari pengolahan tanah, porositas dan jaringan perakaran di Generasi 3 dan 4 sudah lebih banyak.

Fraksi pasir dalam tekstur tanah Generasi 1 sampai 4 mengalami peningkatan terhadap Generasi 0, dapat diartikan bahwa mineralmineral mudah lapuk semakin habis dan mineral-mineral sukar lapuk semakin mendominasi tanah. Hal ini menunjukkan bahwa budidaya kelapa sawit responsif terhadap hara yang dibutuhkan dalam proses budidayanya. Untuk itu, kesuburan tanah perlu dipertahankan dengan best management practise yang tepat dan berkelanjutan. Bulk density pada Lapisan I semua generasi tanam lebih rendah dibandingkan dengan lapisan di bawahnya, ini dikarenakan akar-akar aktif sebagian besar berada pada tanah Lapisan I. Pada saat kemarau, akar sawit berkembang ke arah bawah untuk mencari air didalam profil tanah dapat dilihat akar dapat menembus sampai ke Lapisan V. Itulah sebabnya kadar bahan organik pada Lapisan IV dan V pada Generasi 4 lebih tinggi dari generasi sebelumnya. Dengan adanya pengelolaan lahan yang menerapkan prinsip keberlanjutan pada G1, G2, G3 dan G4 , maka dapat mempertahankan karakteristik bulk density tanah.

Rerata kadar air titik layu permanen ( $\mathrm{pF} 4,2)$ dapat dilihat dari hasil pengukuran pada titik layu permanen seperti pada tabel 6 .

Tabel 6. Uji beda kadar air titik layu permanen (\%) setiap generasi tanam

\begin{tabular}{|l|c|c|c|c|c|c|}
\hline $\begin{array}{l}\text { Gapisan } \\
\text { Lapisan I }\end{array}$ & G0 & G1 & G2 & G3 & G4 & Sig. \\
\hline Lapisan II & 21,74 & 21,02 & 24,59 & 25,72 & 17,78 & $0,106 \mathrm{~ns}$ \\
\hline Lapisan III & 24,44 & 21,40 & 21,78 & 22,48 & 19,80 & $0,857 \mathrm{~ns}$ \\
\hline Lapisan IV & 24,21 & 26,06 & 20,81 & 23,23 & 25,47 & $0,870 \mathrm{~ns}$ \\
\hline Lapisan V & 28,87 & 25,42 & 25,80 & 27,54 & 21,27 & $0,774 \mathrm{~ns}$ \\
\hline
\end{tabular}

Sig.=Signifikansi Oneway ANOVA pada $\alpha$ 5\%, jika Sig. $<\alpha 5 \%=$ signifikan, $n s=$ not significant. 
Berdasarkan uji Anova dari rata-rata nilai kadar air Titik Layu Permanen ( $\mathrm{pF} 4,2$ ) tidak ada perbedaan sigifikan pada setiap generasi tanam. Hal ini sejalan dengan penelitian GerbensLeenes et al, (2009), menemukan bahwa kelapa sawit ternyata termasuk tanaman yang tidak rakus air.

Nilai bulk density (BD) dapat menggambarkan adanya lapisan padat pada tanah yang berkaitan dengan pengolahan tanah, kandungan bahan organik, porositas tanah dan kemudahan akar menembus tanah. Hal ini berkaitan dengan pengolahan tanah pada best management practice (BMP) yang dilakukan di PT Socfin Indonesia, dimana pada saat sebelum tahun 1990 belum menggunakan ripping pada saat itu, sedangkan pada era setelah tahun 1990, pengolahan tanah sudah mulai menggunakan ripping dengan kedalaman $60-70 \mathrm{~cm}$ dari permukaan tanah. Penanaman kacangan (Legume Cover Crops) pada areal peremajaan merupakan tindakan untuk mencegah erosi permukaan menambah bahan organik tanah sejalan dengan sistem manajemen berkelanjutan di PT Socfin Indonesia. Praktik BMP berupa land clearing dengan menggunakan ripping, penanaman legume cover crop ini juga dilakukan perkebunan kelapa sawit lainnya secara konsisten.

Dari Gambar 3 terlihat bahwa terjadi peningkatan porositas tanah walaupun tidak signifikan, hal ini menunjukkan bahwa perkembangan akar kelapa sawit mampu memperbaiki tanah menjadi lebih gembur sehingga pergerakan air tanah menjadi lebih baik dan meningkatkan kemapuan tanah menyimpan atau menahan air. Adanya trend peningkatan porositas tanah setelah penanaman 4 generasi tanam terjadi karena adanya peningkatan volume perakaran dari Lapisan I sampai Lapisan V.

Diketahui bahwa kandungan hara pada tanah ultisol umumnya rendah karena pencucian basa berlangsung intensif, sedangkan kandungan bahan organik rendah karena proses dekomposisi berjalan cepat dan sebagian terbawa erosi. Oleh karena itu, peningkatan produktivitas tanah ultisol dapat dilakukan melalui perbaikan tanah (ameliorasi), pemupukan dan pemberian bahan organik. Peningkatan fraksi liat yang membentuk horizon argilik pada tanah ultisol cukup merugikan karena horizon ini akan menghalangi aliran air secara vertikal, sebaliknya aliran horizontal meningkat sehingga memperbesar daya erosivitas. Pembentukan horizon argilik merupakan proses alami yang sulit dicegah, namun erosi yang terjadi dapat dihindari atau dikurangi dampaknya (Prasetyo dan Suriadikarta, 2006).

Distribusi kadar liat pada penampang profil tanah tidak menggambarkan adanya pencucian liat yang maksimal atau signifikan terutama pada Generasi 3 dan Generasi 4. Curah hujan yang tinggi $\left( \pm 2.500 \mathrm{~mm} \cdot \mathrm{th}^{-1}\right)$ di lokasi penelitian tidak menyebabkan pencucian kation yang tinggi karena akar tanaman kelapa sawit pada Lapisan I dapat menahan laju erosi atau pencucian baik erosi vertikal maupun erosi horizontal. Perakaran tanaman menambah ruang pori tanah sehingga penanaman kelapa sawit dapat mengurangi erosi aliran horizontal sehingga akar atau perakaran tanaman kelapa sawit dapat memperbaiki dan mengkonservasi tanah.

Di Perkebunan Aek Loba dilakukan aplikasi janjang kosong (empty fruit bunch) pada blok-blok dengan kondisi tanah marginal, seperti: berpasir, berbatu atau yang memiliki kadar liat tinggi dan juga diprioritaskan pada Tanaman generasi ketiga dan keempat. Biasanya diberikan pupuk organik berupa janjang kosong dan solid ex decanter pabrik. Pemberian bahan organik berupa aplikasi janjang kosong kelapa sawit dengan dosis 45 Ton $\mathrm{Ha}^{-1}$ pada tahun pertama dan pada tahun berikutnya diaplikasikan solid dengan dosis 45 Ton $\mathrm{Ha}^{-1}$. Pada blok-blok TM kelapa sawit Generasi 3 dan Generasi 4 diaplikasikan janjang kosong dengan dosis 45 Ton. $\mathrm{Ha}^{-1}$ dengan frekuensi 1 x 2 tahun. Hal ini merupakan salah satu usaha untuk perbaikan tanah (ameliorasi) yang dilakukan dalam sistem manajemen berkelanjutan di PT Socfin Indonesia perkebunan Aek Loba. Pada tanah lapisan atas (Lapisan I) yang tebalnya berkisar antara 13 - $32 \mathrm{~cm}$ berwarna gelap dan mengandung bahan organik yang cukup tinggi. Perakaran sawit sebagian besar berada pada 
tanah lapisan atas, akar-akar aktif sawit dapat dikatakan mampu mengkonservasi tanah lapisan atas, sehingga dapat memperlambat degradasi tanah. Pada saat musim kemarau perakaran kelapa sawit akan mencari air sampai ke lapisan bawah.

Warna tanah menunjukkan kandungan Corganik tanah tersebut. Tanah yang berwarna hitam kelam mengandung $\mathrm{C}$-organik yang tinggi. Makin cerah warna tanah kandungan Corganiknya makin rendah. Lapisan I lebih gelap dari pada lapisan di bawahnya pada semua generasi tanam. Menurut Jourdan dan Rey (1997) diperakaran tanaman kelapa sawit, terjadi proses pemangkasan diri (self pruning) yaitu muncul akar-akar yang mempunyai kehidupan lebih pendek daripada bagian induk percabangannya, yang juga biasanya berdiameter lebih besar. Sumber bahan organik pada lahan kelapa sawit yang ditanami terus menerus selama beberapa generasi adalah akar sawit itu sendiri. Hal ini cocok dengan Marshall dan Waring (1985) akar memiliki kehidupan yang telah ditentukan, memiliki takaran yang terbatas karbon yang tersedia, dalam bentuk humus dan akan mati setelah persediaannya telah habis. Akar diameter kecil memiliki persediaan yang lebih kecil dari akar berdiameter besar dan mati lebih dahulu.

Menurut Harahap (1999) luasnya zona perakaran tanaman kelapa sawit memberikan sumbangan terhadap perubahan sifat-sifat tanah, terutama yang terkait dengan dinamika bahan organik tanah yang berasal dari sisa-sisa jaringan akar yang melapuk dan atau pengaruh fisik dan mekanik selama proses pertumbuhan akar yang berlangsung. Tanaman kelapa sawit mampu meningkatkan ruang pori tanah, indeks stabilitas agregat tanah, persentase air tersedia tanah tetapi menurunkan kerapatan lindak tanah terutama pada lapisan permukaan.

\section{SIMPULAN}

Penerapan budidaya kelapa sawit sampai empat generasi secara berkelanjutan di tanah Typic hapludults Perkebunan Aek Loba PT Socfindo menyebabkan perubahan karakteristik tanah yang tidak signifikan, khususnya pada karakteristik fisik tanah (seperti : Bulk Density, Porositas, Kadar Air Tersedia). Tanah Typic hapludults yang ditanam kelapa sawit empat generasi terus menerus di Perkebunan Aek Loba yang dikelola dengan sistem manajemen berkelanjutan ternyata dapat mempertahankan karakteristik fisik tanah.

\section{SARAN}

Perlu penelitian lanjutan yang dilakukan pada jenis tanah yang berbeda. Sehubungan dengan fakta sekitar $60 \%$ areal kebun kelapa sawit di Indonesia dikelola oleh perusahaan perkebunan, maka perlu penelitian kelapa sawit banyak dilakukan di perusahaan perkebunan yang dikelola secara berkelanjutan untuk mendapatkan data yang akurat dalam rangka menjawab kampanye negatif yang masif dituduhkan kepada kelapa sawit nasional. Agar perusahaan perkebunan besar kelapa sawit baik Perkebunan Negara maupun Swasta di Indonesia membuka diri untuk penelitian di lokasi perkebunannya dan bekerja sama dengan perguruan tinggi di daerah masing-masing.

\section{DAFTAR PUSTAKA}

Gerbens-Leenes, Hoekstra P. Van der Meer, T. 2009. The water Footprint of Energy from Biomass: a Quantitative Assesment and Consequences of an Increasing Share of Bioenergy Supply. Ecological Economics 68:4:1052-1060.

Harahap, E. M. 1999. Perkembangan Akar Tanaman Kelapa Sawit pada Tanah Terdegradasi di Sosa Tapanuli Selatan Sumatera Utara. (Disertasi S3). Program Pascasarjana IPB, Bogor.

Hardjowigeno S. 1995. Ilmu Tanah. Akademika Pressindo, Jakarta.

Jourdan, C and Herve Rey. 1997. Architecture and development of the oil-palm (Elaeis guineensis Jacq.) root system. Kluwer Academic Publishers, Netherlands.

Kallarackal, J., Jeyakumar, P. and George. S. J. 2004. Water use of irrigated oil palm at three different arid locations in peninsular India. Journal of Oil Palm Research 16 : 45-53.

Marshall J D and Waring R H. 1985. Predicting fine root production and turnover by 
monitoring root starch and soil temperature. Can J. For. Res. 15, 791-800.

Paramanathan, 2004. Soils of Aek Loba, Aek Nabuntu, Aek Korsik, Aek Loba Timur dan Aek Kwasan Oil Palm Estate Kabupaten Asahan Provinsi Sumatera Utara, Indonesia, Param Agricultural Soil Surveys (M) Sdn Bhd, Selangor, Malaysia.

Prasetyo BH dan Suriadikarta DA. 2006. Karakteristik, Potensi dan Teknologi Pengelolaan Tanah Ultisol Untuk Pengembangan Pertanian Lahan Kering di Indonesia. Jurnal Litbang Pertanian. 25(2). BPT, Bogor.

Socfin Indonesia, 2015. Sistem Manajemen Socfindo : Prosedur Budidaya Kelapa Sawit. (SOC/PSM/7.10). Revised 02, Medan.

Socfin Indonesia, 2016. Laporan Tahunan PT Socfin Indonesia 2015, Medan.

Socfin Medan SA. 1948. Report of The Agricultural Department for the Year Ended 31 December 1948, Medan.
Soil Survey Staff. 2014. Keys to Soil Taxonomy, $12^{\text {nd }}$ edition. USDA-Natural Resources Conservation Service, Washington, DC.

Suganda H, Achmad Rachman, dan S. Sotono. 2006. Petunjuk Pengambilan Contoh Tanah. Sifat Fisik Tanah dan Metode Analisisnya. Balai Besar Litbang Sumberdaya Lahan Pertanian, Badan Penelitian dan Pengembangan Pertanian, Departemen Pertanian.

Utami, SR, Kusuma Z, Kurniawan S. 2013. Dampak Alih Guna Hutan Menjadi Kebun Karet Dan Kelapa Sawit Terhadap Cadangan C Dan N Tanah, Serta Pencucian Nitrogen. Laporan Tahunan Penelitian Unggulan Perguruan Tinggi $(P)$. Fakultas Pertanian Universitas Brawijaya, Malang. Download [http://lppm.ub.ac.id/wp-content/uploads/ 2014/06/Sri-Rahayu-Utami.pdf] 